\title{
Recent evolution of alternative reproductive modes in the 'living fossil' Triops cancriformis Thorid Zierold*1,2,3, Bernd Hanfling ${ }^{1}$ and Africa Gómez ${ }^{1}$
}

\author{
Address: ${ }^{1}$ Department of Biological Sciences, University of Hull, Hull, HU6 7RX, UK, ${ }^{2}$ Institut für Biowissenschaften, Technische Universität \\ Bergakademie Freiberg, Leipziger Strasse 29, D-09599 Freiberg, Germany and ${ }^{3}$ Museum für Naturkunde Chemnitz, DAStietz, Moritzstrasse 20, D- \\ 09111 Chemnitz, Germany \\ Email: Thorid Zierold* - zierold@naturkunde-chemnitz.de; Bernd Hanfling - b.haenfling@hull.ac.uk; Africa Gómez - a.gomez@hull.ac.uk \\ * Corresponding author
}

Published: 13 September 2007

BMC Evolutionary Biology 2007, 7:161 doi:10.1186/147|-2148-7-161
Received: 2I February 2007

Accepted: 13 September 2007

This article is available from: http://www.biomedcentral.com/I47I-2/48/7/I6I

(C) 2007 Zierold et al; licensee BioMed Central Ltd.

This is an Open Access article distributed under the terms of the Creative Commons Attribution License (http://creativecommons.org/licenses/by/2.0), which permits unrestricted use, distribution, and reproduction in any medium, provided the original work is properly cited.

\begin{abstract}
Background: The Notostraca is a small but ancient crustacean order with a contrasting combination of a conservative morphology and a wide range of reproductive modes. The tadpole shrimp Triops cancriformis, includes bisexual - the putatively ancestral state -, androdioecious and hermaphrodite populations. As hermaphroditism and androdioecy confer a colonisation advantage, we expect the postglacial colonisation of northern Europe to have been effected by lineages with such reproductive modes. Therefore, $\mathrm{N}$ European populations should be composed of closely related lineages reflecting a recent range expansion. In contrast, glacial refugia in the south should contain bisexual populations with high haplotype diversity and more population structuring. To test these hypotheses, we analysed the geographic distribution of reproductive modes based on new and published sex ratio data. In addition, we investigated the European phylogeography of $T$. cancriformis by sequencing over a 1000 bp of mitochondrial DNA ( $m t D N A$ ) in individuals from a large sample of populations of the three recognised subspecies.
\end{abstract}

Results: Bisexual populations were only found in the lberian Peninsula, with the rest of European populations showing low male proportions or no males. Androdioecious populations were found in Central and Eastern Europe. Regarding mtDNA diversity, Spanish and Moroccan populations of T. c. mauritanicus were highly divergent, and showed strong population structure. In contrast, Triops c. cancriformis and T. c. simplex formed a single mtDNA lineage with low haplotype diversity. This diversity was structured into two phylogenetic clades (A, B), coexisting in E Germany. Basal haplotypes of both lineages were found in the Iberian Peninsula. Most of the populations in clade $A$ and $B$ are either hermaphroditic or androdioecious, with the only bisexual population in these clades found in the lberian Peninsula. The genetic divergence between these two clades suggests a split in the Late Pleistocene and their geographic distribution reflects a complex evolutionary history of European Triops populations, with possibly two episodes of range expansions - one of them by clade A - involving androdioecious and hermaphroditic populations.

Conclusion: As we predicted, $\mathrm{N}$ European populations of $T$. cancriformis are closely related, with few widely distributed haplotypes and indications of a recent range expansion involving hermaphroditic/androdioecious lineages. A possible second range expansion or long distance colonisation may have created the secondary contact zone between $T$. c. cancriformis/simplex clades $A$ and $B$. The large haplotype diversity and strong genetic subdivision in the lberian Peninsula, which is known to contain only bisexual populations, strongly suggest that this area was a Pleistocene refugium for $T$. cancriformis, although the occurrence of additional eastern refugia cannot be ruled out. Our data support the status of $T$. c. mauritanicus as a separate species and the colonisation of N Africa from the lberian Peninsula. We suggest that hermaphroditism/androdioecy has evolved recently in $T$. cancriformis and has facilitated the postglacial colonisation of northern Europe. 


\section{Background}

The widespread occurrence of outcrossing sexual reproduction has puzzled evolutionary biologists since Darwin, as reproduction either through self-fertilisation or parthenogenesis provides immediate advantages [1,2]. One of such key advantages is evident during the colonisation process $[3,4]$, as a single selfing hermaphrodite or parthenogenetic individual can found a new population. Organisms with mixed reproductive strategies allow a unique direct comparison of the relative advantages of different reproductive modes [5,6]. Mixed strategies often have a geographic component (e.g. 'geographical parthenogenesis') which reflects the interplay between historical and selective factors [6]. The process of recolonisation of northern areas during interglacial periods of the Pleistocene might have favoured passively dispersing parthenogens or selfing hermaphrodites. As a consequence, in temperate organisms with mixed reproductive strategies, hermaphroditism is often found in areas previously covered by glaciers or permafrost and therefore, recolonisation must have taken place after the last glacial maximum. Despite this, ecological correlates have been intensively sought to explain such geographic patterns adaptively $[5,7]$, whereas the phylogeographic context of mixed reproductive patterns has only recently begun to be investigated [8-10].

The Eurasian tadpole shrimp Triops cancriformis (Crustacea: Branchiopoda: Notostraca) has a mixed reproductive strategy which includes hermaphroditism, androdioecy (consisting of hermaphrodites and a small proportion of males) and bisexuality $[11,12]$, the latter being considered to be the ancestral condition [13]. The currently recognized subspecies T. c. simplex (N Africa and NE Iberian Peninsula) and T. c. mauritanicus (NW Morocco and SW Iberian Peninsula) are considered to be bisexual, with equal or male biased sex ratios $[14,15]$. The nominal subspecies T. c. cancriformis, occurring in central and northern Europe and a disjunct area in Japan, includes hermaphrodite and androdioecious populations [16,17]. The reproductive strategy in $T$. c. cancriformis populations is controversial, although there is evidence to suggest that 'females' are in fact hermaphrodites as they can reproduce in isolation [18] and ovotestes are present [12]. However, females from a German T. c. cancriformis population apparently lacked testicular tissue [19] suggesting that parthenogenesis - or a mixture of bisexual and hermaphroditic reproduction in some populations - cannot be ruled out. Our preliminary microsatellite data [20] show significant heterozygote deficiencies in many populations, and genotyping of individuals reared in isolation and their offspring supports hermaphroditism. Thus, and following Sassaman [11] we consider some T. c. cancriformis populations to be androdioecious, as populations consist of variable proportions of hermaphrodites and males, with some populations being made solely of selfing hermaphrodites. As in other androdioecious branchiopods, T. c. cancriformis hermaphrodites can reproduce either by selfing or by outcrossing with males.

T. cancriformis inhabits temporary freshwater ponds and all three reproductive modes lead to the production of resistant diapausing cysts, which survive in the pond sediments during drought periods. These cysts are also the means of passive dispersal by wind, water currents or downstream floods, and birds [21-23], amphibians or hoofed animals [24-26]. An indication of the vagility of such cysts is that populations occur on remote islands, and are apparently found wherever suitable habitats are available [27]. Evidence for wide notostracan distribution before the Pleistocene can be derived from its abundant fossil record dating back to the Carboniferous or possibly up to the Devonian period [28]. In fact, the striking morphological similarity of some Upper Triassic Triops sp. fossils from Germany and extant T. cancriformis [29] makes this notostracan one of the best examples of morphological stasis and 'living fossils' [30]. Thus, the potentially high dispersal abilities of their diapausing cysts and the possibility of hermaphrodite reproduction could account for the wide distribution of $T$. cancriformis.

Here we present a phylogeographic analysis of European $T$. cancriformis in the context of its reproductive mode variation. So far, attempts at investigating the genetic variability of $T$. cancriformis have been hampered by its low genetic variability $[31,32]$, therefore our phylogeographic survey of $T$. cancriformis is based on sequence variation on over 1000 bp of mitochondrial DNA containing highly informative mitochondrial genes. We hypothesize, in agreement with Longhurst [18], that hermaphrodite or androdioecious populations should occur in areas unsuited for the species during Pleistocene glacial maxima (either covered with ice sheets or permafrost), and that therefore must have been recently colonised. Further, N European populations should be composed of one or few closely related lineages reflecting a recent range expansion of hermaphroditism and/or androdioecy. In contrast, glacial refugia in S Europe should contain bisexual populations with high haplotype diversity and high population structuring. To test these hypotheses, we analysed the geographic distribution of inferred reproductive modes based on reviewed and re-analysed data concerning sex-ratio in this species and new critical data of our own. In addition, we screened a large sample of populations of the three recognised subspecies for nucleotide sequence variation in two mtDNA genes (COI and ATPase). The phylogeographic pattern is interpreted in the context of the inferred population reproductive mode. Our results provide insights into the evolution of reproductive mode and population diversification in Triops. 


\section{Results}

\section{mtDNA haplotype diversity}

A total of $84 T$. cancriformis individuals from 29 ponds were sequenced for two mitochondrial gene fragments: a 568 bp sequence of the cytochrome $c$ oxidase 1 gene (COI) and a 506 bp fragment comprising partial sequences of ATP synthase $\mathrm{F}_{\mathrm{O}}$ subunits 8 (ATP8) and 6 (ATP6) genes (Table 1, Figure 1). Given that the partitionhomogeneity test did not find significant differences between both fragments ( $p$-value of 0.07), we combined them into a single alignment with a total length of 1074 bp for phylogenetic analysis.

Overall 213 variable nucleotide sites, 158 of them parsimony informative, were identified in the combined alignment. Excluding the Iberian (Extremadura, EXT; Ares del Maestre, ARE) and Moroccan (Youssofia, YOI) T. c. mauritanicus specimens, 38 sites remained variable and 26 sites were parsimony informative. Comparing the COI and ATPase (including ATP8 and 6 genes) fragments separately we found within the COI fragment a total of 20 substitutions on $1^{\text {st }}$ codon position, 3 on $2^{\text {nd }}$ and 91 on $3^{\text {rd }}$ positions, which resulted in nine amino acid changes. The ATPase fragment is characterised by 46 changes on $1^{\text {st }}$ codon position, 22 on $2^{\text {nd }}$ and 99 at $3^{\text {rd }}$ codon position which result in 33 amino acid changes. The combined alignment was moderately $\mathrm{A}+\mathrm{T}$ rich (mean $\mathrm{AT}$ content = $65.2 \%)$.

Despite sequencing over 1000 bp of mtDNA, overall haplotype diversity was low, with only $19 \mathrm{mtDNA}$ haplotypes identified in the combined alignment. Eleven of those haplotypes were found in the 14 T. c. cancriformis populations sampled. Fourteen out of the nineteen identified

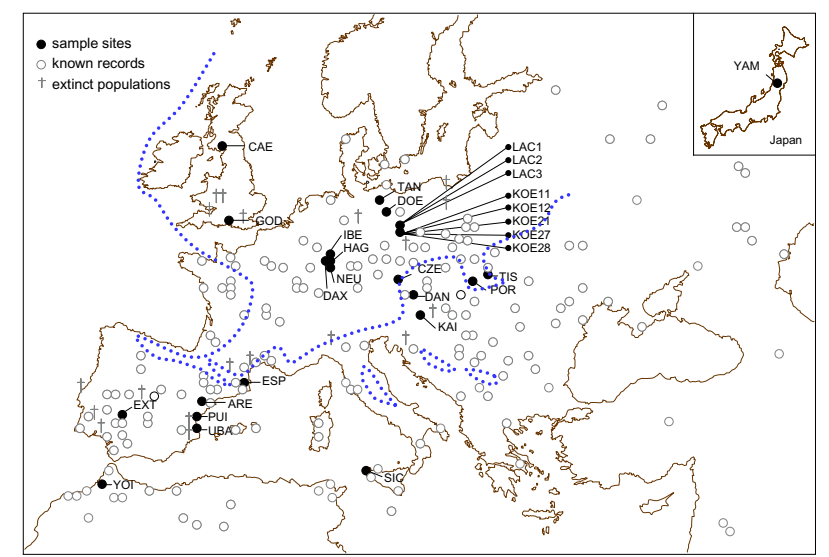

\section{Figure I}

European distribution of Triops cancriformis showing the location of sampled populations. The dotted line indicates the continuous permafrost in the last glacial maximum (50 00012000 years ago) [74]. haplotypes were found in single populations (Table 1, Figure 2), while one haplotype (H8) was found in two nearby populations in Germany (DAX, HAG), H13 was found in a set of four nearby ponds in the area of Königswartha, and H1, H2 and H3 were common and widespread, found in six, nine and three ponds respectively. $\mathrm{H} 1$ was found in the Iberian individuals from Espolla (ESP) and El Puig (PUI), which had been previously identified as T. c. simplex [33], as well as in individuals of the nominal subspecies from Döberitzer Heide (DOE), Königswartha pond 12 and 21 (KOE12, KOE21) and Rhine (DAX).

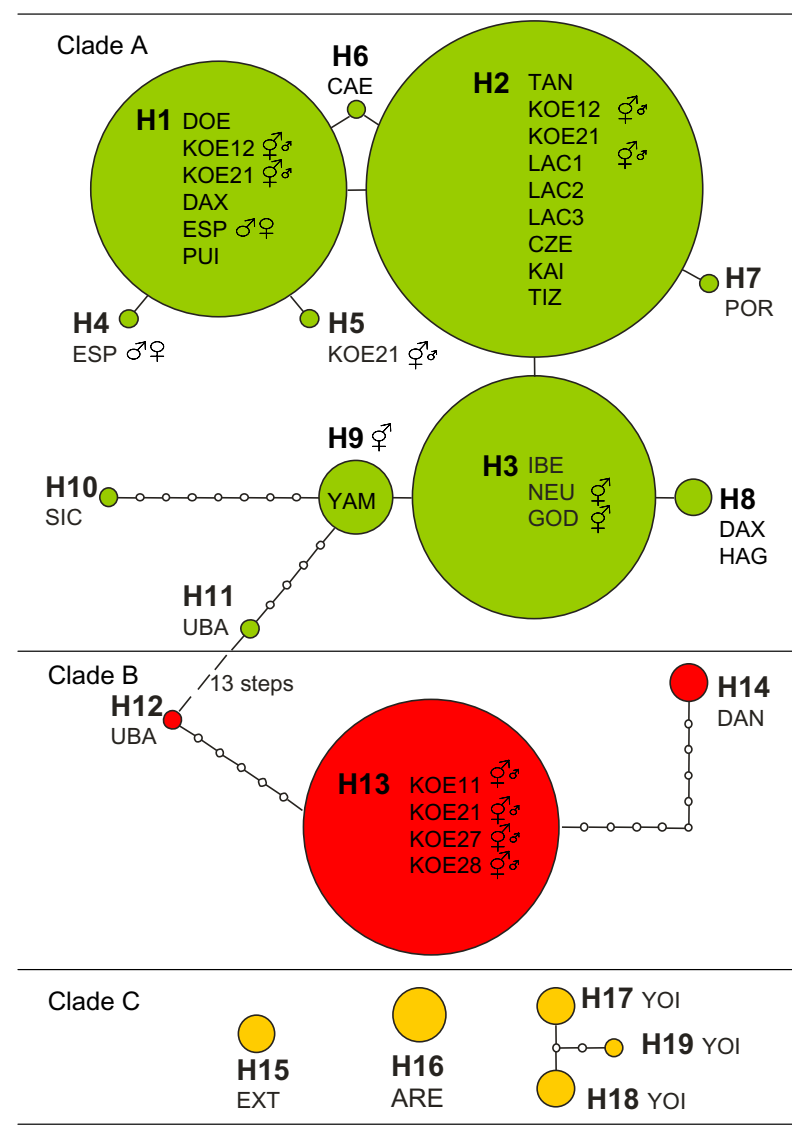

Figure 2

Maximum parsimony network of Triops cancriformis based on combined $\mathrm{COI}$ and ATPase sequence data. Each circle represents a different haplotype, with its diameter proportional to the haplotype sample size. Each line between haplotypes represents a mutation. Populations containing each haplotype and their reproductive mode (if known) are indicated. Reproductive mode symbols as in Figure 3. Haplotypes of $T$. c. mauritanicus could not be joined to the T. c. cancriformis/ simplex network or between themselves without exceeding the limits of parsimony, and form three disjointed networks. 
The number of haplotypes per population ranged from 14 (average 1.35), with the maximum found in Königswartha (KOE21) (Table 1). Given the low level of genetic diversity found in our preliminary analysis, we optimised our resources by increasing the number of bp sequenced per individual and the number of populations surveyed, instead of the number of individuals sequenced per population.

\section{Phylogenetic relationships}

Both maximum likelihood and Bayesian analyses produced identical topologies showing two highly divergent and strongly supported monophyletic lineages (Figure 3 ). The first lineage is represented by T. c. mauritanicus haplotypes (nucleotide diversity $\pi=0.05905$ ) (clade $\mathrm{C}$ ). The second lineage includes all haplotypes from the subspecies T. c. cancriformis and T. c. simplex $(\pi=0.00920)$. Despite the low genetic diversity within T. $c$. cancriformis/ simplex, two divergent clades (A and B) were identified. The closely related haplotypes $\mathrm{H} 1$ to $\mathrm{H} 9$ within clade A occurred from E Spain to $\mathrm{N}$ and $\mathrm{C}$ Europe and the Japa-

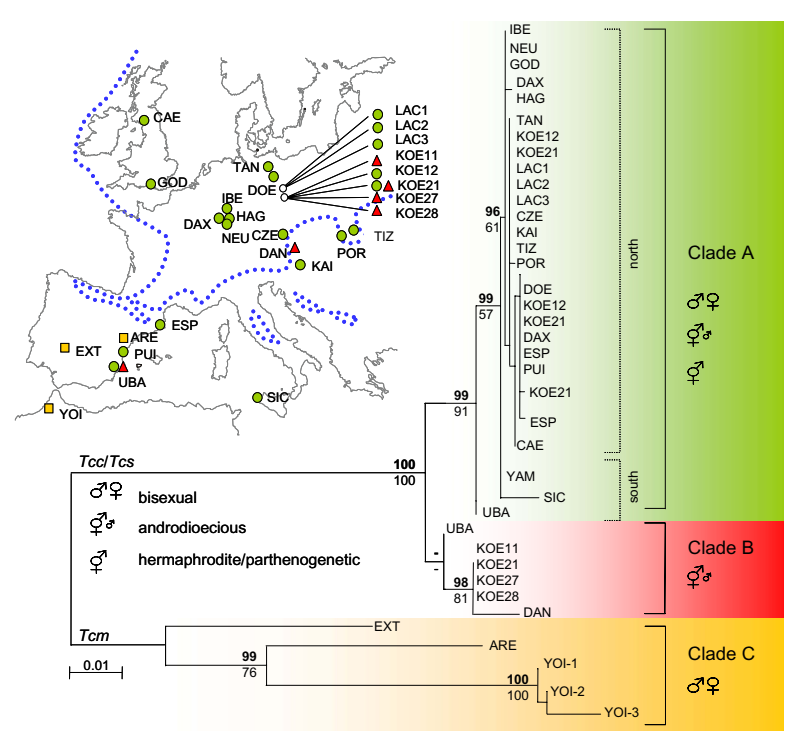

\section{Figure 3}

Maximum likelihood (ML) tree obtained from the combined $\mathrm{COI}$ and ATPase sequence alignment and the distribution of COI-ATP Triops cancriformis haplotypes in Europe (Tcc/s, Triops cancriformis cancriformis/simplex; Tcm, Triops cancriformis mauritanicus). In the phylogram, values above major branches are posterior probabilities in the Bayesian analysis; numbers below indicate the bootstrap support in the Maximum likelihood analysis (only values over $50 \%$ are shown). The tree is midpoint rooted. Inferred reproductive mode in populations of each clade is indicated by symbols. In the different clades are represented by coloured symbols in the map (green circles for clade $A$; red triangles for clade $B$; yellow squares for clade C). nese population $(\pi=0.00114)$ (see network in Figure 2 ). This group includes the three most common and widespread haplotypes (H1, H2, H3) and a cluster of rare, geographically restricted haplotypes differing from them in single substitutions. In contrast, haplotypes from the southern populations within clade A (H10, Sicily and H11, UBA in Spain) are more divergent and differ in 9 and 6 respectively substitutions from H3. The two morphologically described subspecies T. c. cancriformis and T. c. simplex, which show different reproductive modes, are not represented by distinct monophyletic lineages, as T. c. simplex individuals from some East Iberian populations (PUI, ESP) share haplotype $\mathrm{H} 1$ with five T. $c$. cancriformis individuals from four different populations in Germany. Clade $\mathrm{B}$ was only found in three disjunct locations (KOE, DAN, UBA, see Figure 3). Haplotypes from clades A and B were present in Königswartha populations. Population UBA from eastern Spain contained the basal haplotype of clade A (H11) - the most internal haplotype in the network - and a haplotype of unresolved position (H12) according to the phylogenetic analyses, but which appears as most closely related to clade B from our network analysis under the limits of parsimony (Figure 2), and therefore was included in clade $\mathrm{B}$. The root of the T. $c$. cancriformis/simplex lineage lies in between both haplotypes in this population, which seems to have retained ancestral polymorphisms in the species.

\section{Sequence divergence and approximation of divergence times}

Based on the combined alignment, pair-wise nucleotide differences among all $T$. cancriformis haplotypes ranged from 1 to $137 \mathrm{bp}$ which translate into a maximum distance (HKY + G corrected) of $14.38 \%$ (H5 vs. H17). The mean corrected distances between clades for the combined alignment and for the COI and ATPase fragments separately are shown in Table 2 . The genetic distance between clades $\mathrm{A}$ and $\mathrm{B}$, including the two recognized subspecies T. c. cancriformis and T. c. simplex, is less than $3.5 \%$. The mean genetic distance was considerable higher $(>10 \%)$ between haplotypes from clade A and B together (T. c. cancriformis and T. c. simplex) and clade C (T. c. mauritanicus).

Calculating the corrected distances separately for the COI and ATPase fragment resulted in higher values for the ATPase alignment. This illustrates, that ATPase is evolving faster and provides more information regarding intraspecific relationships than COI (Table 2).

The crustacean COI calibration applied to obtain an approximate time of divergence between the T. c. cancriformis/simplex group (clades A and B) and T. c. mauritanicus (clade C), yielded 4.71-7.85 mya (around the Miocene-Pliocene boundary) (Table 2). The divergence 
Table I: Triops cancriformis sample locations, population code, location of inferred subspecies, source of material, number of individuals sequenced for $\mathrm{COI}$ and ATPase and observed haplotypes (and numbers individuals per haplotype) per population, geographic are given based on the combined $\mathrm{COI}$ and ATPase analysis.

\begin{tabular}{|c|c|c|c|c|c|c|}
\hline Location & Code & $\begin{array}{l}\text { Geographic } \\
\text { location }\end{array}$ & Species & Material & $\mathbf{n}$ & Haplotype \\
\hline Caervalerock, UK & CAE & $\begin{array}{l}54^{\circ} 08^{\prime} 27^{\prime \prime} \mathrm{N} \\
003^{\circ} 30^{\prime} 58^{\prime \prime} \mathrm{E}\end{array}$ & Tcc & $\mathrm{P}$ & 1 & $\mathrm{H} 6(\mathrm{I})$ \\
\hline Tannen, Germany & TAN & $\begin{array}{l}53^{\circ} 34^{\prime} 10^{\prime \prime} \mathrm{N}, \\
011^{\circ} 25^{\prime} 34^{\prime \prime} \mathrm{E}\end{array}$ & Tcc & $\mathrm{P}$ & 1 & $\mathrm{H} 2(\mathrm{I})$ \\
\hline $\begin{array}{l}\text { Döberitzer Heide, } \\
\text { Germany }\end{array}$ & DOE & $\begin{array}{l}\left.52^{\circ} 3\right|^{\prime} 43^{\prime \prime} \mathrm{N}, \\
013^{\circ} 00^{\prime} 05^{\prime \prime} \mathrm{E}\end{array}$ & Tcc & $\mathrm{h}$ & 2 & $\mathrm{HI}(2)$ \\
\hline Lacoma, Germany & $\mathrm{LACl}$ & $\begin{array}{l}51^{\circ} 48^{\prime} 12^{\prime \prime} N \\
014^{\circ} 24^{\prime} 02^{\prime \prime} \mathrm{E}\end{array}$ & Tcc & $\mathrm{h}$ & 2 & $\mathrm{H} 2(2)$ \\
\hline Lacoma, Germany & LAC2 & $\begin{array}{l}51^{\circ} 48^{\prime} 05^{\prime \prime} \mathrm{N} \\
014^{\circ} 23^{\prime} 37^{\prime \prime} \mathrm{E}\end{array}$ & Tcc & $\mathrm{h}$ & 3 & $\mathrm{H} 2(3)$ \\
\hline Lacoma, Germany & LAC3 & $\begin{array}{l}51^{\circ} 47^{\prime} 47^{\prime \prime} \mathrm{N} \\
014^{\circ} 23^{\prime} 3 I^{\prime \prime} \mathrm{E}\end{array}$ & Tcc & $\mathrm{h}$ & 2 & $\mathrm{H} 2(2)$ \\
\hline \multirow[t]{2}{*}{$\begin{array}{l}\text { Königswartha, } \\
\text { Germany }\end{array}$} & KOEI2 & $\begin{array}{l}51^{\circ} 19^{\prime} 50^{\prime \prime} \mathrm{N}, \\
014^{\circ} 18^{\prime} 30^{\prime \prime} \mathrm{E}\end{array}$ & Tcc & $\mathrm{h}$ & 3 & $\mathrm{HI}(\mathrm{I})$ \\
\hline & & & & & & $\mathrm{H} 2(2)$ \\
\hline $\begin{array}{l}\text { Königswartha, } \\
\text { Germany }\end{array}$ & KOEII & $\begin{array}{l}51^{\circ} 19^{\prime} 49^{\prime \prime} \mathrm{N} \\
\left.014^{\circ} 18^{\prime} 3\right|^{\prime \prime} \mathrm{E}\end{array}$ & Tcc & $\mathrm{h}$ & 3 & $\mathrm{HI} 3(3)$ \\
\hline $\begin{array}{l}\text { Königswartha, } \\
\text { Germany }\end{array}$ & KOE28 & $\begin{array}{l}51^{\circ} 19^{\prime} 48^{\prime \prime} \mathrm{N}, \\
014^{\circ} 18^{\prime} \mid 2^{\prime \prime} \mathrm{E}\end{array}$ & Tcc & $P$ & 4 & $\mathrm{HI} 3(4)$ \\
\hline $\begin{array}{l}\text { Königswartha, } \\
\text { Germany }\end{array}$ & KOE27 & $\begin{array}{l}51^{\circ} 19^{\prime} 46^{\prime \prime} \mathrm{N} \\
014^{\circ} 18^{\prime} \mid 4^{\prime \prime} \mathrm{E}\end{array}$ & Tcc & $\mathrm{P}$ & 3 & $\mathrm{HI} 3(3)$ \\
\hline \multirow[t]{4}{*}{$\begin{array}{l}\text { Königswartha, } \\
\text { Germany }\end{array}$} & KOE2I & $\begin{array}{l}51^{\circ} 19^{\prime} 43^{\prime \prime} \mathrm{N}, \\
014^{\circ} 18^{\prime} 23^{\prime \prime} \mathrm{E}\end{array}$ & Tcc & $\mathrm{h}$ & 9 & $\mathrm{HI}(\mathrm{I})$ \\
\hline & & & & & & $\mathrm{H} 2(3)$ \\
\hline & & & & & & $\mathrm{H} 5$ (I) \\
\hline & & & & & & $\mathrm{HI} 3(4)$ \\
\hline Godshill pond, UK & GOD & $\begin{array}{l}50^{\circ} 55^{\prime} 37^{\prime \prime} \mathrm{N}, \\
001^{\circ} 46^{\prime} 30^{\prime \prime} \mathrm{E}\end{array}$ & Tcc & $\mathrm{h}$ & 8 & H3 (8) \\
\hline Ibersheim, Germany & IBE & $\begin{array}{l}49^{\circ} 43^{\prime} 41 " \mathrm{~N} \\
008^{\circ} 25^{\prime} 55^{\prime \prime} \mathrm{E}\end{array}$ & Tcc & $\mathrm{h}$ & 2 & $\mathrm{H} 3(2)$ \\
\hline \multirow[t]{2}{*}{$\begin{array}{l}\text { Daxlander Au, } \\
\text { Germany }\end{array}$} & DAX & $\begin{array}{l}49^{\circ} 01 \text { I' } 10 " \mathrm{~N} \\
008^{\circ} 17^{\prime} 00^{\prime \prime} \mathrm{E}\end{array}$ & Tcc & c & 2 & $\mathrm{HI}(\mathrm{I})$ \\
\hline & & & & & & H8 (I) \\
\hline Hagenbach, Germany & HAG & $\begin{array}{l}49^{\circ} 00^{\prime} 40^{\prime \prime} \mathrm{N} \\
008^{\circ} 16^{\prime} 25^{\prime \prime} \mathrm{E}\end{array}$ & Tcc & $\mathrm{h}$ & 1 & $\mathrm{H} 8(\mathrm{I})$ \\
\hline Neuburg, Germany & NEU & $\begin{array}{l}48^{\circ} 59^{\prime} 30^{\prime \prime} \mathrm{N} \\
008^{\circ} 16^{\prime} 25^{\prime \prime} \mathrm{E}\end{array}$ & Tcc & $\mathrm{h}$ & 3 & $\mathrm{H} 3(3)$ \\
\hline $\begin{array}{l}\text { Morava, Czech } \\
\text { Republic }\end{array}$ & CZE & n.d. & Tcc & $\mathrm{h}$ & 1 & $\mathrm{H} 2(\mathrm{I})$ \\
\hline Danube, Austria & DAN & n.d. & $\mathrm{Tcc}$ & c & 2 & HI4 (2) \\
\hline Tiszabercel, Hungary & $\mathrm{TIZ}$ & $\begin{array}{l}48^{\circ} 10^{\prime} 38^{\prime \prime} \mathrm{N} \\
021^{\circ} 37^{\prime} 18^{\prime \prime} \mathrm{E}\end{array}$ & Tcc & $\mathrm{P}$ & 1 & $\mathrm{H} 2(\mathrm{I})$ \\
\hline Kaiserlacke, Austria & KAl & $\begin{array}{l}47^{\circ} 47^{\prime} 40^{\prime \prime} \mathrm{N}, \\
016^{\circ} 52^{\prime} 3 I^{\prime \prime} \mathrm{E}\end{array}$ & Tcc & $\mathrm{h}$ & 3 & $\mathrm{H} 2(3)$ \\
\hline Poroszlo, Hungary & POR & $\begin{array}{l}47^{\circ} 39^{\prime} \mathrm{O} / \mathrm{N} \mathrm{N} \\
020^{\circ} 43^{\prime} 37^{\prime \prime} \mathrm{E}\end{array}$ & Tcc & $\mathrm{P}$ & 1 & $\mathrm{H} 7(\mathrm{I})$ \\
\hline \multirow[t]{2}{*}{ Espolla, Spain } & ESP & $\begin{array}{l}42^{\circ} 09^{\prime} 02^{\prime \prime} \mathrm{N}, \\
002^{\circ} 45^{\prime} 60^{\prime \prime} \mathrm{E}\end{array}$ & Tcs* & $\mathrm{P}$ & 7 & $\mathrm{HI}(6)$ \\
\hline & & & & & & $\mathrm{H} 4(\mathrm{I})$ \\
\hline $\begin{array}{l}\text { Ares del Maestre, } \\
\text { Spain }\end{array}$ & ARE & $\begin{array}{l}40^{\circ} 25^{\prime} 19^{\prime \prime} N \\
000^{\circ} 04^{\prime} 13^{\prime \prime} \mathrm{W}\end{array}$ & $\mathrm{Tcm} *$ & $\mathrm{P}$ & 3 & $\mathrm{HI} 6(3)$ \\
\hline El Puig, Spain & PUI & $\begin{array}{l}39^{\circ} 34^{\prime} 24^{\prime \prime} \mathrm{N}, \\
000^{\circ} 16^{\prime} 43^{\prime} \mathrm{E}\end{array}$ & Tcs* & $\mathrm{P}$ & 3 & $\mathrm{HI}(3)$ \\
\hline $\begin{array}{l}\text { Laguna de la } \\
\text { Gitanilla, Spain }\end{array}$ & EXT & $\begin{array}{l}39^{\circ} 27^{\prime} 00^{\prime \prime} \mathrm{N}, \\
006^{\circ} 15^{\prime} 54^{\prime \prime} \mathrm{W}\end{array}$ & $\mathrm{Tcm} *$ & $\mathrm{P}$ & 1 & HI5 (I) \\
\hline \multirow[t]{2}{*}{$\begin{array}{l}\text { Ullal de Baldovi, } \\
\text { Spain }\end{array}$} & UBA & $\begin{array}{l}39^{\circ} 14^{\prime} 55^{\prime \prime} \mathrm{N} \\
000^{\circ} 19^{\prime} 03^{\prime \prime} \mathrm{E}\end{array}$ & Tcs & $\mathrm{P}$ & 2 & HII (I) \\
\hline & & & & & & $\mathrm{HI} 2(\mathrm{I})$ \\
\hline $\begin{array}{l}\text { Gorgo di Baglio } \\
\text { Cofano Sicily, Italy }\end{array}$ & SIC & $\begin{array}{l}38^{\circ} 06^{\prime} 11 \mathrm{I}^{\prime \prime} \mathrm{N}, \\
012^{\circ} 40^{\prime} 39^{\prime \prime} \mathrm{E}\end{array}$ & Tcc & $\mathrm{P}$ & 2 & $\mathrm{HIO}(2)$ \\
\hline $\begin{array}{l}\text { Yamagata } \\
\text { Prefercture, Japan }\end{array}$ & YAM & $\begin{array}{l}38^{\circ} 02^{\prime} 58^{\prime \prime} \mathrm{N}, \\
140^{\circ} 10^{\prime} 48^{\prime \prime} \mathrm{E}\end{array}$ & Tcc & $\mathrm{P}$ & 4 & H9 (4) \\
\hline \multirow[t]{3}{*}{ Youssofia, Morocco } & YOI & $\begin{array}{l}32^{\circ} 17^{\prime} 06^{\prime \prime} \mathrm{N}, \\
008^{\circ} 19^{\prime} 22^{\prime \prime} \mathrm{W}\end{array}$ & $\mathrm{Tcm}$ & $\mathrm{P}$ & 5 & HI7 (2) \\
\hline & & & & & & HI8 (2) \\
\hline & & & & & & $\mathrm{HI}(\mathrm{I})$ \\
\hline
\end{tabular}

p, preserved individuals collected in the wild; h, preserved individuals from laboratory rearing; c, cyst 
Table 2: Mean corrected percent sequence divergences between Triops cancriformis clade/population comparisons and estimated divergence times based on corrected COI distance. Distances are given for the combined COI-ATPase fragment as well as separately for COI and ATPase sequences. Because no crustacean molecular clock calibration factors are available for ATPase we used the COI corrected distance for approximations of divergence times. For population codes see Table I, for clade definition see Figure 2.

\begin{tabular}{lllllll}
\hline & \multicolumn{3}{c}{ Corrected \% sequence divergence } & & \multicolumn{2}{c}{ Estimated divergence times (mya) } \\
\cline { 2 - 3 } clade/population & COI-ATP & ATP & COI & & $\begin{array}{l}\text { I.4\% sequence } \\
\text { divergence per mya }\end{array}$ & $\begin{array}{l}\text { 2.3\% sequence } \\
\text { divergence per mya }\end{array}$ \\
\hline clade A vs. clade B & 2.1590 & 3.4323 & 1.5865 & & 1.1332 & 0.6809 \\
clade A and B vs. C & 13.5477 & 44.5345 & 10.985 & & 7.8465 & 4.7146 \\
ARE vs. YOI & 9.7768 & 24.3929 & 7.9947 & & 5.6762 & 3.4106 \\
ARE\&YOI vs. EXT & 10.4396 & 31.5413 & 7.8278 & & 5.5912 & 3.3595 \\
\hline
\end{tabular}

time between clades A and B was estimated to have happened during the Early Pleistocene (0.68-1.13 mya).

\section{Distribution of inferred reproductive modes in Triops cancriformis}

Bisexuality was supported in two Portuguese populations of T. c. mauritanicus (Algarve) and one Spanish population of T. c. simplex (Espolla) (Table 3, Figure 4). Androdioecy was inferred for populations in Central and E Europe (Table 3). Populations with male proportions above 0.100 were identified mainly from eastern European populations (Poland and Hungary). As listed in Table 3, maleless populations occur in Germany, France, Poland and United Kingdom, and no males have been reported from Italian, Polish and Japanese populations (with no reported sample sizes) [17,34-36]. As androdioecious populations can have low proportion of males it can not

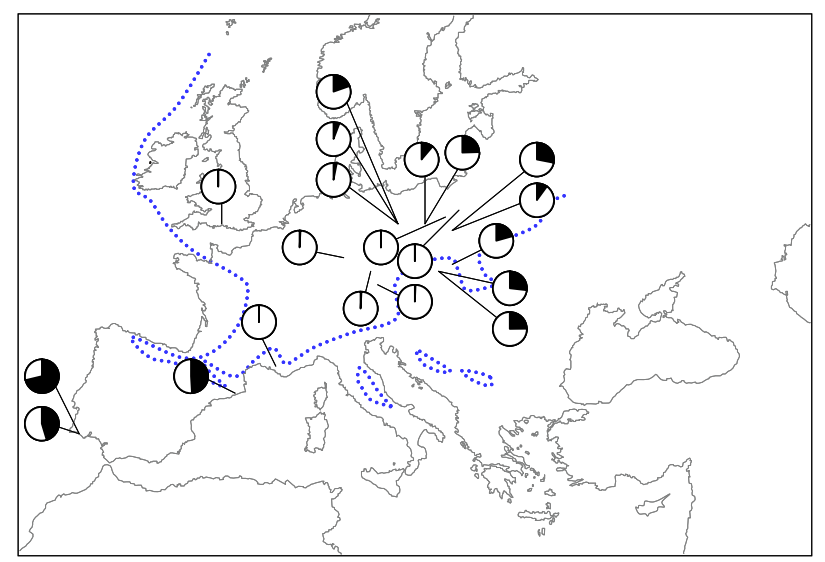

\section{Figure 4}

Geographic variation of male proportions in Triops cancriformis (for data and references see Table 3). The pie charts show the proportion of males in black for each population with sample size over 25 . The dotted line indicates the maximal extent of permafrost in the last glacial maximum [74]. be excluded that those population are actually androdioecious. In populations where males have been recorded male proportions ranged from 0.012 to 0.281 (Table 3). As shown in Figure 4 both androdioecious and putatively hermaphrodite populations are distributed where no suitable habitats for $T$. cancriformis were found during the Pleistocene ice ages.

\section{Discussion}

As we predicted, T. cancriformis haplotypes from most $\mathrm{N}$ European populations and the disjunct Japanese population - clustered in clade A - are closely related, with a few, widely distributed haplotypes. The reduced genetic diversity in T. cancriformis is a consistent and remarkable result of our data. This can be supported by the large mitochondrial fragment we investigated, the selection of the most rapid evolving gene in Triops and extensive sampling. A low mitochondrial diversity in T. cancriformis was noted by Mantovani et al. [32] and Korn et al. [31] based on $16 \mathrm{~S}$ and $12 \mathrm{~S}$ sequences, which are slowly evolving compared to our fragments. Furthermore, preliminary data on diversity of nuclear microsatellite loci $[20,37]$ suggested low genome wide polymorphism in T. c. cancriformis/simplex [20]. This pattern supports postglacial range expansion of T. c. cancriformis/simplex lineages into areas which were unsuitable for this species during the last glacial maximum. When we take the phylogeographic and reproductive mode results together, the predominance of androdioecious and potentially hermaphroditic populations in formerly glacial or permafrost regions strongly suggests that lineages with alternative reproductive modes were responsible for the postglacial recolonization of $\mathrm{N}$ Europe, as hypothesized by Longhurst [18]. Our results with $T$. cancriformis closely resemble the pattern found in geographic parthenogenesis. The term geographical parthenogenesis is used for the tendency of parthenogenetic populations to be distributed in high latitudes reflecting an association between parthenogenesis and environments that were strongly affected by the Pleistocene glacial cycles $[6,38]$. Several organisms have been described 
Table 3: Sex ratio and inferred reproductive mode in European Triops cancriformis. The number (n) of individual males and females/ hermaphrodites and the male proportion per pond are given. The results of the Chi-Square test to infer deviations from a null hypothesis of equal sex ratio and the inferred type of reproductive mode are provided (see text). In the populations investigated here, the collection year is indicated under the Reference heading.

\begin{tabular}{|c|c|c|c|c|c|c|}
\hline Location & $\mathbf{n}_{\text {male }}$ & $\begin{array}{r}\mathbf{n}_{\text {female/her- }} \\
\text { maphrodite }\end{array}$ & prop. of males & $\begin{array}{l}\text { p value } \\
\text { (Chi-Square) }\end{array}$ & $\begin{array}{l}\text { Inferred reproductive } \\
\text { mode }\end{array}$ & Reference \\
\hline Baillargues, France & 0 & 200 & 0.000 & $<0.0001$ & hermaphrodite & {$[35]$} \\
\hline Neuburg, Germany & 0 & 102 & 0.000 & $<0.0001$ & hermaphrodite & own data (2004-2006) \\
\hline Jaktorów, Poland & 0 & 40 & 0.000 & $<0.0001$ & hermaphrodite & {$[75]$} \\
\hline Zabieniec, Poland & 0 & 40 & 0.000 & $<0.0001$ & hermaphrodite & {$[75]$} \\
\hline $\begin{array}{l}\text { Godshill pond, } \\
\text { United Kingdom }\end{array}$ & 0 & 25 & 0.000 & $<0.0001$ & hermaphrodite & this paper (2004-2006) \\
\hline $\begin{array}{l}\text { Königswartha } \\
\text { (KOE25), Germany }\end{array}$ & 2 & 32 & 0.059 & $<0.0001$ & androdioecious & this paper (2006) \\
\hline Bavaria, Germany & 8 & 1000 & 0.008 & $<0.0001$ & androdioecious & {$[76]$} \\
\hline Augsburg, Germany & 7 & 568 & 0.012 & $<0.0001$ & androdioecious & {$[77]$} \\
\hline $\begin{array}{l}\text { Königswartha } \\
\text { (KOEI2), Germany }\end{array}$ & 10 & 95 & 0.095 & $<0.0001$ & androdioecious & this paper (2004 to 2006 ) \\
\hline Cracow, Poland & 16 & 144 & 0.100 & $<0.0001$ & androdioecious & {$[78]$} \\
\hline $\begin{array}{l}\text { Königswartha } \\
\text { (KOE27), Germany }\end{array}$ & 14 & 123 & 0.102 & $<0.0001$ & androdioecious & this paper (2006) \\
\hline Wroclaw, Poland & 114 & 912 & 0.111 & $<0.0001$ & androdioecious & [79] \\
\hline $\begin{array}{l}\text { unknown location, } \\
\text { Hungary }\end{array}$ & 9 & 34 & 0.209 & 0.0001 & androdioecious & {$[80]$} \\
\hline Wroclaw, Poland & 29 & 88 & 0.248 & $<0.0001$ & androdioecious & [79] \\
\hline $\begin{array}{l}\text { Lake Balaton, } \\
\text { Hungary }\end{array}$ & 15 & 45 & 0.250 & 0.0001 & androdioecious & {$[81]$} \\
\hline $\begin{array}{l}\text { Lake Balaton, } \\
\text { Hungary }\end{array}$ & 7 & 19 & 0.269 & 0.0186 & androdioecious & {$[81]$} \\
\hline Cracow, Poland & 154 & 395 & 0.281 & $<0.0001$ & androdioecious & [78] \\
\hline Algarve, Portugal & 19 & 23 & 0.452 & $0.537 \mid$ & bisexual & {$[82]$} \\
\hline Algarve, Portugal & 54 & 22 & 0.711 & 0.0002 & bisexual & {$[82]$} \\
\hline Espolla, Spain & 64 & 57 & 0.529 & 0.5245 & bisexual & this paper (2006) \\
\hline Espolla, Spain & 1723 & 1775 & 0.493 & 0.3872 & bisexual & [33] \\
\hline
\end{tabular}

having parthenogenetic populations in $\mathrm{N}$ and C Europe and sexual populations in restricted southern areas $[39,40]$. Although T. cancriformis populations, being hermaphroditic, do not fulfil the geographical parthenogenesis concept, they would enjoy the colonisation advantage in a comparable way. Therefore we suggest broadening the concept of geographical parthenogenesis by introducing the term 'geographical hermaphroditism'.

In contrast to the pattern found in N Europe with populations of low genetic diversity and alternative reproductive modes, southern $T$. cancriformis populations, including all the identified bisexual populations, show high and geographically structured haplotype diversity. These results support the hypothesis that bisexual populations are characterised by reduced gene flow and high interpopulation divergence (regional differentiation as found between Iberian T. c. mauritanicus populations), possibly because the areas inhabited by these populations have been suitable for longer. Similar strong geographic structuring of genetic variation with very isolated populations has been reported from other sexual European large branchiopods (Anostracans) $[41,42]$. These strong population structures despite high potential for gene flow through their diapausing propagules suggests that Triops populations and other large branchiopods, in a similar way to continental zooplankton undergo a process of 'Monopolisation' of their habitats [43]. The presence of ancestral haplotypes and strong genetic subdivision in the Iberian Peninsula, strongly points to this area as a Pleistocene refugium for $T$. cancriformis. This inference is further supported by the presence of bisexual populations for T. c. mauritanicus and T. c. simplex in the Iberian Peninsula. However, the genetic divergence between clades A and B and their geographic distribution indicates that the phylogeographic history of European T. cancriformis is more complex as these clades are likely to have diverged earlier than the last glacial cycle. Clade B is especially puzzling as it is present only in three locations including northern and southern populations. Different scenarios could explain this pattern. One of these is the possibility that $\mathrm{N}$ European populations from clade B are derived from an early postglacial expansion which left relict populations in an Eastern refugium - Balkans, Middle East - which we did not sample, a pattern that has previously been reported for the European fire salamander [44]. Another explanation could be long 
distance colonisation events facilitated by the passive dispersal of Triops diapausing cysts as reported for other aquatic invertebrates $[45,46]$. Either way, this possible range expansion/long distance colonisation event - comparable to clade A - was linked to androdioecious lineages, which is the reproductive mode, present in clade B. In summary we suggest a split in the Late Pleistocene that originated clades A and B in T. c. cancriformis/simplex, with an early refugium in the Iberian Peninsula and possibly a second one. Further sampling from eastern populations and further Mediterranean islands where the species is known to occur should shed light into this issue. Subsequently these lineages underwent possibly two episodes of range expansions/long distance colonisation, in both cases involving hermaphroditic and/or androdioecious populations. Interestingly, those populations we infer to be androdioecious, occur in the area where both clades coexist in Germany. The occurrence of hybridisation between these clades is suggested by our microsatellite data [20] as two of the populations where both lineages coexist (KOE) and have been analysed with microsatellite loci display Hardy Weinberg equilibrium [20].

We suggest that geographic isolation within the Iberian Peninsula, possibly dating back to the Miocene-Pliocene boundary, led to the initial divergence between T. c. mauritanicus and T. c. cancriformis/simplex lineages and also to genetic isolation among T. c. mauritanicus populations in the Northwest and Southeast Iberian Peninsula. Such regional persistence suggests that long-term suitable habitats were available in separate areas within the Iberian Peninsula throughout the Pliocene and Pleistocene. Deep phylogeographic splits within the Iberian Peninsula have been observed in a wide range of taxa, indicating either the existence of several independent Pleistocene refugia within this area [47] or colonisation of the southern Iberian Peninsula from North Africa $[48,49]$. Our analyses, containing Moroccan samples, indicate that the Iberian populations of T. c. mauritanicus are basal, which supports a scenario in which T. . mauritanicus would have colonised North Africa from the Iberian Peninsula, possibly during the early Pliocene. A similar pattern of colonisation from the Iberian Peninsula into North Africa has been documented for lizards and amphibians [50-52]. Therefore, we suggest that the Iberian Peninsula provided a long-term subdivided glacial refugium for both $T$. $c$. mauritanicus and T. c. cancriformis/simplex.

The combined alignment of COI and ATPase sequences showed that T. c. mauritanicus and T. c. cancriformis/simplex form two highly divergent monophyletic lineages, as also suggested by a $16 \mathrm{~S}$ and $12 \mathrm{~S}$ analysis [31]. The estimated $13.55 \%$ sequence divergence between both lineages is within the range separating other notostracan [53] and crustacean species [54]. Our data therefore provide strong support to the proposal of Korn et al. [31] to reinstate $T$. c. mauritanicus to species status, as originally described by Ghigi [55]. In contrast, the traditional subdivision into the subspecies T. c. cancriformis and T. c. simplex sensu Longhurst [27] could not be supported by our data as the populations representing T. c. simplex (ESP, PUI, UBA) shared either a genetic haplotype with T. c. cancriformis populations or were very closely related to them. We propose that the validity of $T$. cancriformis simplex should be reconsidered.

\section{Conclusion}

Our analysis of $T$. cancriformis reproductive mode in the context of its phylogeography allowed us to gain insights into the role of alternative reproductive modes during Pleistocene range shifts. We suggest that hermaphroditism/androdioecy has evolved recently, possibly in the Late Pleistocene and has facilitated the postglacial colonisation of northern Europe from one or two refugia, one of them likely placed in the Iberian Peninsula. Despite generally low genetic variability in T. cancriformis we were able to identify mitochondrial regions which provided sufficient resolution to reveal phylogeographic patterns across Europe. Our data support a taxonomic revision of T. cancriformis. The occurrence of three different reproductive modes within closely related genetic lineages of a single species make $T$. cancriformis a good model to investigate the evolution of mixed reproductive strategies.

\section{Methods \\ Samples}

A total of 29 water bodies in inundated floodplains, isolated ponds, puddles and fish nursery pools containing $T$. cancriformis populations were sampled in Europe, Japan and Morocco between 2000 and 2006 (Table 1, Figure 1). Overall 23 populations belong to the nominal subspecies, T. c. cancriformis, 3 populations were identified as the subspecies T. c. simplex and 3 populations belong to T. c. mauritanicus (Table 1). Samples included specimens collected using a dip net ( $5 \mathrm{~mm}$ pore diameter), and sediment containing diapausing cysts from dry ponds where the species was known to occur. Once specimens were needed for genetic analyses, and to be able to obtain sex ratio data, sediment was placed at the bottom of glass tanks and distilled water added to induce hatching of cysts. Individuals were grown until maturity and fed daily with fish flakes ad libitum.

\section{Amplification and Sequencing}

Total genomic DNA was isolated from ethanol-preserved tissue using commercial DNA extraction kits (Invisorb Spin Forensic Kit, Invitek; PureGene Kit, Gentra Systems). For the populations DAN and DAX, where attempts to hatch specimens from the sediment were unsuccessful, DNA was extracted from single cysts isolated from the sed- 
iment following procedures described in Gómez \& Carvalho [56] (Table 1).

Given that our preliminary studies based on sequence variation at mitochondrial $16 \mathrm{~S}$ and COI genes provided little resolution for intraspecific relationships within $T$. cancriformis [20] we decided to explore the published T. cancriformis and $T$. longicaudatus mitochondrial genomes in order to identify the most variable regions for a phylogeographic survey. We designed primers within highly conserved regions identified from an alignment of four branchiopoda sequences, Triops cancriformis (GenBank accession number NC 004465), Triops longicaudatus (NC 006079), Daphnia pulex, (DQ340834) and Artemia franciscana ( $\underline{\mathrm{X} 69067})$. The set of primers are available from the authors under request. We then carried out a preliminary survey of genetic variation for nine mitochondrial genes (ATP6, ATP8, cytb, ND2, ND3, ND5, ND4, ND4L and the D-loop) using eight $T$. cancriformis individuals from different populations. As a result ATP8 and ATP6 in combination with COI proved to be the most diverse fragments in terms haplotype and nucleotide diversity (data available from the authors upon request). Consequently these loci were chosen to complement our preliminary COI data.

A 568 bp fragment of COI was amplified and sequenced using primers LCO1490 and HCO2198 [57]. A second fragment of $506 \mathrm{bp}$, covering parts of the ATP 8 and parts of the ATP6 gene, was amplified using newly designed Triops specific primers. The $5^{\prime}$ primer, ATP-Tc-3800U (5'TCTAATCCCCCAAATAGCCCCTAGT- 3 '), is located in the tRNA $^{\text {Asp }}$ (corresponding to sites 3800 to 3825 in the reference sequence NC_004465), and the 3' primer, ATP-Tc4405L (5'-ACAGCAAGAGTTCCGGGACGAATA-3') is located in the ATP6 mtDNA (sites 4381 to 4405 in the reference sequence NC_004465).

Amplifications were performed in $20 \mu \mathrm{l}$ final volume containing $2 \mu \mathrm{l}$ template DNA, $1.5 \mathrm{mM} \mathrm{MgCl}, 200 \mu \mathrm{M}$ of each nucleotide, $100 \mu \mathrm{M}$ of each primer, $0.01 \mathrm{U}$ of Taq DNA polymerase and $1 \times \mathrm{NH}_{4}$-PCR Buffer (Bioline). The following cycling conditions were used: 3 min denaturating at $93^{\circ} \mathrm{C},\left(45 \mathrm{~s}\right.$ at $94^{\circ} \mathrm{C}, 45 \mathrm{~s}$ at $50^{\circ} \mathrm{C}, 1 \mathrm{~min}$ at $\left.72^{\circ} \mathrm{C}\right)$ $\times 35,5 \mathrm{~min}$ extension at $72^{\circ} \mathrm{C}$. PCR products were sequenced directly using the PCR primers and the Beckman DTCS Quick Start Sequencing kit in a Beckman CEQ8000 capillary sequencer. The sequences were checked by eye with the CEQ 8000 data analyser and initially aligned with Clustal W [58] and finally adjusted by hand. Sequences for the COI, ATP6 and ATP8 fragments were obtained for all individuals. All the sequences were deposited in GenBank (accession numbers EF675826EF675991).

\section{Phylogenetic reconstructions}

A partition-homogeneity test [59] was performed using PAUP*4.0 [60] on the COI and ATPase datasets to determine whether datasets were congruent and could be combined for phylogenetic analyses.

Phylogenetic relationships were reconstructed using maximum-likelihood and Bayesian approaches. The best fitting, least-parameter rich model of sequence evolution was based on hierarchical likelihood-ratio test in the program ModelGenerator0.6 [61]. This method identified the $\mathrm{HKY}+\mathrm{G}$ model of sequence evolution and four gamma distributed rate categories as the optimal model. This model of sequence evolution and its parameter estimates were used to perform a maximum likelihood (ML) algorithm in PHYML 2.4.4 [62]. Branch support of the ML tree was assessed by 1000 bootstrap pseudo-replications. MRBAYES 3.1.1 [63] was used to generate a Bayesian reconstruction by running a Markov chain for 2,000,000 generations and using a burn-in of 2500 . The $50 \%$ consensus tree was obtained from the remaining trees from both runs sampled after the initial burn-in period.

Nodes in the ML-tree were considered to be well supported if they showed at least 70\% bootstrap support [64]. Similarly, strong branch support was inferred in the Bayesian analyses when posterior probabilities were over $80 \%$ [65]. Trees were displayed with NJPlot [66]. To examine the geographic and reproductive mode associations of haplotypes a haplotype network was constructed using TCS1.21 [67].

\section{Molecular clock estimates}

Unfortunately, the abundant fossil record of Triopsidae is not informative for molecular calibration purposes mainly due to the morphological stasis of the group since the Carboniferous period (about $302 \mathrm{Ma}$ ) [28,68-70]. Therefore, currently, fossil data provide no information on splits within Triops. In consequence, no direct calibration points were available within the Triops phylogeny precluding the application of methods to estimate divergence times such as suggested by Sanderson [71]. In order to provide a rough approximation of divergence times among $T$. cancriformis lineages we used two crustacean clock calibrations of Knowlton and Weigt [72] (1.4\% sequence divergence per million years) and Schubart et al. [73] (1.66-2.33\% sequence divergence per million years). Both calibrations are based on COI data and consequently we used only the COI fragment from our data set to estimate divergence times. Corrected average pairwise genetic sequence (using the best fit model for the COI dataset, $\mathrm{TVM}+\mathrm{G}$ ) between haplotypes were used in all divergence time estimates. 


\section{Sex ratio and reproductive mode}

Sex ratio was determined for all $T$. cancriformis populations sampled in this study either from wild-caught specimens or from individuals hatched in the laboratory from sediment samples. Sexing was carried out on fixed specimens under a dissecting microscope. We considered an individual was a male when no egg sac was found in the $11^{\text {th }}$ pair of thoracopods. No external diagnostic character allows discriminating between females and hermaphrodites; therefore, we calculated the sex ratio as the number of males divided by the number of female/hermaphrodites. Furthermore we included published data for 21 European populations in order to understand the geographic distribution of sex ratios. We only included literature data that provided either sample sizes and the sex ratio, or the raw numbers of males and females/hermaphrodites per sample. Sex ratio was used to distinguish between three potential reproductive modes for each population: bisexual reproduction was inferred when the sex ratio did not significantly differ from 1 based on a binominal Chi-square test; androdioecy was inferred when males where present but the sex ratio deviated significantly from 1; populations in which no males where found were treated as potentially hermaphroditic populations. Note, however, that such populations could also represent androdioecy with low frequency of males.

\section{Authors' contributions}

$\mathrm{TZ}$ participated in the design of the study, carried out the molecular genetic studies, sequence alignment and sexratio analysis and drafted the manuscript. BH participated in the design of the study and the statistical analysis and helped to draft the manuscript. AG conceived the study, and participated in its design, the analysis and interpretation of data and helped to draft and revise the manuscript it critically for important intellectual content. All authors read and approved the final manuscript.

\section{Acknowledgements}

We are grateful to J. deWaard, who sent us unpublished $T$. australiensis $\mathrm{COI}$ and $16 \mathrm{~S}$ sequences. We thank Drs. J. L. Pérez-Bote, J. Rueda Sevilla, F. Mezquita, J. K. Vanderkerkhove, D. Boix Sala, L. Griffin, A. Petrusek, L. Simon, M. Kawata, L. Forró, F. Suhling, L. Simon and M. Korn for kindly providing samples. D. Boix Sala provided us with unpublished data from his PhD thesis. D. H. Lunt, R. L. Hammond, M. Engelmann and two anonymous referees provided constructive comments and discussion in earlier versions of the manuscript. This research was supported by grants from NERC (NE/ D007496/I), HERI and the German Environmental Foundation (DBU 20002/243). We further wish to thank English Nature, Scottish Heritage and the Sieland Foundation (Germany) for sample permissions.

\section{References}

I. Otto SP, Lenormand T: Resolving the paradox of sex and recombination. Nat Rev Genet 2002, 3:252-26I.

2. Bell GD: The Masterpiece of Nature: The Evolution and Genetics of Sexuality Berkley and Los Angeles: University of California Press; 1982.

3. Baker HG: Self-compatibility and establishment after "longdistance" dispersal. Evolution 1955, 9:347-348.
4. Baker HG: Support for Baker's Law-as a rule. Evolution I967, 2I:853-856.

5. Peck JR, Yearsley JM, Waxman D: Explaining the geographic distributions of sexual and asexual populations. Nature 1998, 391:889-892.

6. Kearney MR: Hybridization, glaciation and geographical parthenogenesis. Trends Ecol Evol 2005, 20:495-502.

7. Kearney MR: Why is sex so unpopular in the Australian desert? Trends Ecol Evol 2003, I 8:605-607.

8. Schon I, Gandolfi A, Di Masso E, Rossi V, Griffiths HI, Martens K, Butlin RK: Persistence of asexuality through mixed reproduction in Eucypris virens (Crustacea, Ostracoda). Heredity 2000, 84: $161-169$

9. Kearney MR, Blacket MJ, Strasburg JL, Moritz C: Waves of parthenogenesis in the desert: evidence for the parallel loss of sex in a grasshopper and a gecko from Australia. Mol Ecol 2006, I 5: 1743-1748.

I0. Law JH, Crespi BJ: The evolution of geographic parthenogenesis in Timema walking-sticks. Mol Ecol 2002, I I:|47|- |489.

II. Sassaman C: Sex ratio variation in female-biased populations of Notostracans. Hydrobiologia 1991, 2 I 2:169-179.

12. Zaffagnini $F$, Trentini $M$ : The distribution and reproduction of Triops cancriformis (Bosc) in Europe (Crustacea Notostraca). Monitore Zool ltal (NS) 1980, I 4: I-8.

13. Pannel JR: The evolution and maintenance of androdioecy. Ann Rev Ecol Syst 2002, 33:397-425.

14. Machado M, Cristo M, da Fonseca LC: Non-cladoceran branchiopod crustaceans from southwest Portugal. I Occurrence notes. Crustaceana 1999, 72:591-602.

15. Boix D, Sala J, Moreno-Amich R: Population dynamics of Triops cancriformis (Crustacea: Branchiopoda: Notostraca) of the Espolla temporary pond in the northeastern Iberian peninsula. Hydrobiologia 2002, 486: $175-183$.

16. Engelmann M, Hahn T: Vorkommen von Lepidurus apus, Triops cancriformis, Eubranchipus (Siphonophanes) grubei, Tanymastix stagnalis und Branchipus schaefferi in Deutschland und Österreich (Crustacea: Notostraca und Anostraca). Faun Abh 2005, 25:3-67.

17. Scanabissi Sabelli F, Eder E, Cesari M: Male occurrence in Austrian populations of Triops cancriformis and ultrastructural observations of the male gonad. Invertebr Biol 2005, 1 24:57-65.

18. Longhurst AR: Evolution in the Notostraca. Evolution 1955, 9:84-86.

19. Engelmann M, Hahn T, Hoheisel G: Ultrastructural characterization of the gonads of Triops cancriformis (Crustacea, Notostraca) from populations containing both females and males: no evidence for hermaphroditic reproduction. Zoomorphologie 1997, I I 7: 175-180.

20. Zierold T: Morphological variation and genetic diversity of Triops cancriformis (Crustacea: Notostraca) and their potential for understanding the influence of postglacial distribution and habitat fragmentation Freiberg: Technische Universität Bergakademie Freiberg; 2006. PhD thesis

21. Càceres CE, Soluk DA: Blowing in the wind: a field test of overland dispersal and colonisation by aquatic invertebrates. Oecologia 2002, I 3 I:402-408.

22. Green AJ, Figuerola J: Recent advances in the study of long-distance dispersal of aquatic invertebrates via birds. Diversity and Distributions 2005, I I: | 49-156.

23. Brendonck L, Riddoch $B$ J: Wind-borne short-range egg dispersal in anostracans (Crustacea: Branchiopoda). Biol J Linn Soc 1999, 67:87-95.

24. Frank PW: Conchostraca. Palaeogeogr Palaeoclimatol Palaeoecol 1986, 62:399-403.

25. Thiery A: Multispecies coexistence of branchiopods (Anostraca, Notostraca \& Spinicaudata) in temporary ponds in Chaouia plain (western Morocco): sympatry or syntopy between usually allopatric species. Hydrobiologia I99I, 21 2:117-136.

26. Bohonak AJ, Whiteman $\mathrm{HH}$ : Dispersal of the fairy shrimp Branchinecta coloradensis (Anostraca): Effects of hydroperiod and salamanders. Limnol Oceanogr 1999, 44:487-493.

27. Longhurst AR: A Review of the Notostraca. Bull Br Mus (Nat Hist) Zool 1955, 3: I-57.

28. Tasch P: Evolution of the Branchiopoda. In Phylogeny and evolution of Crustacea Edited by: Whittington HB, Rolfe WD. Harvard University; 1963:145-162. 
29. Trusheim F: Triopsiden (Crust. Phyll.) aus dem Keuper Frankens. Palaeontol Z 1937, 19:198-216.

30. Futuyma DJ: Evolutionsbiologie Basel, Boston, Berlin: Birkhäuser; 1990.

31. Korn M, Marrone F, Pérez-Bote JL, Machado M, Cristo M, da Fonseca C, Hundsdoerfer AK: Sister species within Triops cancriformis lineage (Crustacea, Notostraca). Zool Scripta 2006, 35:30I-322.

32. Mantovani B, Cesari M, Scanabissi Sabelli F: Molecular taxonomy and phylogeny of the 'living fossil' lineages Triops and Lepidurus (Branchiopoda: Notostraca). Zool Scripta 2004, 44:367-374.

33. Boix D: Estructura i dinàmica de la comunitat animal aquàtica de l'estanyol temporani d'Espolla. PhD Dissertation. Institut d'Ecologia Aquàtica Girona: Universitat de Girona; 2002.

34. Simon E: Etude sur les Crustacés du sous-ordre des Phyllopodes. Ann Soc Entomol France 1886, 6:393-460.

35. Mathias P: Biologie des crustaces phyllopodes Paris: Hermann \& Cie; 1937.

36. Akita M: Classification of Japanese tadpole shrimps. Zool Magazine 1976, 85:237-247.

37. Cesari M, Mularoni L, Scanabissi Sabelli F, Mantovani B: Characterization of dinucleotide microsatellite loci in the living fossi shrimp Triops cancriformis (Crustacea: Branchiopoda: Notostraca). Mol Ecol Notes 2004, 4:733-735.

38. Vandel $\mathrm{A}$ : La parthénogénèse géographique. Contribution à l'ètude biologiquie et cytologique de la parthénogénèse naturelle. Bull Biol France, Belgique 1928, 12:164-28I.

39. Schoen I: Did Pleistocene glaciations shape genetic patterns of Europe ostracodes? A phylogeographic analysis of two species with asexual reproduction. Hydrobiologia 2007, 575:33-50.

40. Knebelsberger $\mathrm{T}$, Bohn $\mathrm{H}$ : Geographic parthenogenesis in the subaptera-group of Phyllodromica (Blattoptera, Blattellidae, Ectobiinae). Insect Syst Evol 2003, 34:427-452.

4I. Ketmaier V, Mandatori R, De Matthaeis E, Mura G: Molecular systematics and phylogeography in the fairy shrimp (Tanymastix stagnalis) based on mitochondrial DNA. J Zool 2005, 266:I-I0.

42. Ketmaier V, Zarattini P, De Matthaeis E, Cobolli M, Mura G: Intraand inter-specific relationships in the six Italian species of the fairy shrimp genus Chirocephalus: combining allozyme and mtDNA data. J Zool Syst Evol Research 2003, 41:276-285.

43. de Meester L, Gómez A, Okamura B, Schwenk K: The monopolization hypothesis and the dispersal-gene flow paradox in aquatic organisms. Acta Oecol 2002, 23:12I-135.

44. Steinfartz $S$, Veith M, Tautz D: Mitochondrial sequence analysis of Salamandra taxa suggests old splits of major lineages and postglacial recolonizations of Central Europe from distinct source populations of Salamandra salamandra. Mol Ecol 2000, 9:397-410.

45. Gómez A, Carvalho GR, Lunt DH: Phylogeography and regional endemism of a passively dispersing zooplankter: $m$ tDNA variation of rotifer resting egg banks. Proc $R$ Soc Lond B 2000, 267:2189-2197.

46. De Gelas K, De Meester L: Phylogeography of Daphnia magna in Europe. Mol Ecol 2005, 14:753-764.

47. Gómez A, Lunt DH: Refugia within refugia: patterns of phylogeographic concordance in the Iberian Peninsula. In Phylogeography in Southern European Refugia: Evolutionary Perspectives on the origins and conservation of European Biodiversity Chapter IV Edited by: Weiss S, Ferrad D. Dordrecht, The Netherlands: Springer; 2007:155-188

48. Martínez-Solano I: Phylogeography of Iberian Discoglossus (Anura: Discoglossidae). J Zool Syst Evol Research 2004, 42:298-305.

49. Veith M, Mayer C, Samraoui B, Barroso DD, Bogaerts S: From Europe to Africa and vice versa: evidence for multiple intercontinental dispersal in ribbe salamanders (Genus Pleurodeles). J Biogeogr 2004, 31: 159-171

50. Harris DJ, Carranza S, Arnold EN, Pinho C, Ferrand N: Complex biogeographical distribution of genetic variation within Podarcis Wall lizards across the Strait of Gibraltar. J Biogeogr 2002, 29:1257-1262

5I. Carranza S, Harris DJ, Arnold EN, Batista V, Gonzalez de la Vega JP: Phylogeography of the lacertid lizard, Psammodromus algirus, in Iberia and across the Strait of Gibraltar. J Biogeogr 2006 33:1279-1288.
52. Vargas JM, Real R, Guerrero JC: Biogeographical regions of the Iberian peninsula based on freshwater fish and amphibian distributions. Ecography 1998, 21:371-382.

53. King JL, Hanner R: Cryptic species in a "living fossil" lineage: Taxonomic and phylogenetic relationships within the genus Lepidurus (Crustacea: Notostraca) in North America. Mol Phylogenet Evol 1998, 10:23-36.

54. Hebert PDN, Ratnasingham S, deWaard JR: Barcoding animal life: cytochrome $c$ oxidase subunit I divergences among closely related species. Proc $R$ Soc Lond B (Suppl) 2003, 270:S96-S99.

55. Ghigi A: Ricerche sui notostraci di Cirenaicae di altri paesi del mediterraneo. Atti Soc Ital Sci nat 1921, 60:161-188.

56. Gómez A, Carvalho GR: Sex, parthenogenesis and genetic structure of rotifers: microsatellite analysis of contemporary and resting egg bank populations. Mol Ecol 2000, 9:203-2/4.

57. Folmer O, Black M, Hoeh W, Lutz R, Vrijenhoek R: DNA primers for amplification of mitochondrial cytochrome $c$ oxidase subunit I from diverse metazoan invertebrates. Mol Mar Biol Biotechnol 1994, 3:294-299.

58. Thompson JD, Higgins DG, Gibson TJ: CLUSTAL W: improving the sensitivity of progressive multiplesequence alignment through sequence weighting, position-specific gap penalties and weight matrixchoice. Nucleic Acids Res 1994, 22:4673-4680.

59. Farris JS, Källersjo M, Kluge A, Bult C: Testing significance of incongruence. Cladistics 1994, 10:315-319.

60. Swofford DL: PAUP*: Phylogenetic Analysis Using Parsimony. 1998.

6I. Keane TM, Naughton TJ, Mclnerney JO: ModelGenerator: amino acid and nucleotide substitution model selection, Version 0.6. 2004 .

62. Guindon S, Gascuel O: PHYML, version 2.4.4. 2003

63. Ronquist F, Huelsenbeck JP: MrBayes 3: Bayesian phylogenetic inference under mixed models. Bioinformatics 2003, 19:1572-1574.

64. Hillis DM, Bull J]: An empirical test of bootstrapping as a method for assessing confidence in phylogenetic analysis. Syst Biol 1993, 42:182-192.

65. Wittingham LA, Silkas B, Winkler DW, Sheldon F: Phylogeny of tree swallow, Tachycineta (Aves: Hirundinidae), Bayesian analysis of mitochondrial DNA sequences. Mol Phylogenet Evol 2002, 22:430-44I.

66. Pierrière G, Gouy M: WWW-Query: An online retrieval system for biological sequence banks. Biochemie 1996, 78:364-369.

67. Clement M, Posada D, Crandall KA: TCS: a computer program to estimate gene genealogies. Mol Ecol 2000, 9:1657-1659.

68. Fryer G: A new classification of the branchiopod Crustacea. Zool J Linnean Soc 1987, 91 1:357-383.

69. Wallossek D: The Upper Cambrian Rehbachiella and the phylogeny of Branchiopoda and Crustacea. Fossils and Strata 1993, 32: I-202.

70. Wallossek D: The Upper Cambrian Rehbachiella, its larval development, morphology and significance for the phylogeny of Branchiopoda and Crustacea. Hydrobiologia 1995, 298: I-I3.

7I. Sanderson MJ: Estimating absolute rates of molecular evolution and divergence times: a penalized likelihood appoach. Mol Biol Evo 2002, 19:101-109.

72. Knowlton N, Weigt LA: New dates and new rates for divergence across the Isthmus of Panama. Proc $R$ Soc Lond B 1998 , 265:2257-2263.

73. Schubart CD, Diesel R, Hedges SB: Rapid evolution to terrestrial life in Jamaican crabs. Nature 1998, 393:363-365.

74. Finlayson C, Carrión JS: Rapid ecological turnover and its impact on Neanderthal and other human populations. Trends Ecol Evol 2007, 22:213-222.

75. Hempel-Zawitkowska J: Some remarks on morphological variability in Triops cancriformis (Bosc). Zool Poloniae 1968, I8:30I-316.

76. Heidecke D, Neumann V: Zur Verbreitung und Ökologie von Triops cancriformis BOSC und Lepidurus apus L. in der DDR. Hercynia N F 1987, 24:166-173.

77. Gaschott O: Beobachtungen und Versuche an Triops cancriformis (Bosc). Zool Anz 1928, 75:267-280.

78. Kozubowsky A: Über den männlichen Apus cancriformis (L.). $Z$ Naturgesch $1857,23: 312-318$. 
79. Braem F: Bemerkungen über die Gattung Apus. Z wissenschaftl Zool 1893, 56:165-187.

80. von Siebold CTE: Beiträge zur Parthenogenesis der Arthropoden Leipzig: Verlag W. Engelmann; 187I.

81. Abonyi S: The males of Apus cancriformis (Schäffer), described on the base of the specimens collected in the region of the lake Balaton biological station of Révfülöp. Arch Balaton 1926, I:7I-90.

82. Machado M, Cristo M, Reis J, da Fonseca C: Biological data on Triops cancriformis mauritanicus (Ghigi, I92I) and Cyzicus grubei (Simon, 1886) - Crustacea, Branchiopoda - in SW Portugal temporary ponds. Limnetica 1999, 16:1-7.

Publish with Bio Med Central and every scientist can read your work free of charge

"BioMed Central will be the most significant development for disseminating the results of biomedical research in our lifetime."

Sir Paul Nurse, Cancer Research UK

Your research papers will be:

- available free of charge to the entire biomedical community

- peer reviewed and published immediately upon acceptance

- cited in PubMed and archived on PubMed Central

- yours - you keep the copyright

Submit your manuscript here:

http://www.biomedcentral.com/info/publishing_adv.asp
BiolMedcentral 